\title{
The Chinese Diaspora, Foreign Investment and Economic Development in China
}

\author{
ALAN SMART AND JINN-YUH HSU
}

The opening of China to the capitalist world after 1979 was done in a spatial sequence designed to mobilize the resources of the overseas Chinese, with the Special Economic Zones located in the key areas of migrant origins. Including the 'compatriots' (tongbao) of Hong Kong, Macao and Taiwan, the great majority of foreign direct investment in China has come from the Chinese diaspora. Local development patterns have been strongly affected by the extent, or lack, of emigrant connections. This article examines the impact on local development of the mobilization of resources from the diaspora. Second, it is suggested that a new stage in the relationship is developing, where the capital of the overseas Chinese is becoming less significant, at least in richer areas such as the Pearl River Delta, as the differentials between Chinese inside and outside are changing. Some new patterns of transnational connections seem to be emerging, however, as China strategically endeavors to develop a knowledge-based economy. The effective interactions between overseas Taiwanese in Silicon Valley and the high-tech sector in Taiwan may be seen as a model for similar processes that are emerging between Taiwanese and certain regions of China, particularly in the Shanghai region.

Rapid growth of China's economy since 1979 has been a critical part of its increased global influence, much more so than have its increased military or diplomatic capacities. As Jiang Zemin stressed in a speech in 2001, China 'knows what it needs most is a peaceful environment in which it can develop its economy and increase its strength'. ${ }^{1}$ Absorbing large amounts of foreign direct investment (FDI) has in turn been a significant dimension of this economic success, not so much as a predominant component of total investment, but as a facilitator of hard currency exports and source of knowledge about and access to global markets. By avoiding current account deficits and indebtedness through reliance on loans, China may also have been able to retain a greater degree of

\footnotetext{
Alan Smart is Professor at the Department of Anthropology, the University of Calgary, Alberta, Canada. Jinn-yuh Hsu is currently an associate professor in Geography at the National Taiwan University.
} 
economic autonomy compared to transition economies in Central and Eastern Europe.

Globalization is an intensely contested term, and even the existence of it as a novel phenomenon is widely criticized as dependent on hyperbole that neglects the intensity of cross-border exchanges in the nineteenth century and before. ${ }^{2}$ We consider globalization to consist of the stretching of human activities and their consequences across national borders and around the world. The core processes of globalization are widely seen as involving the creation of a global capitalist economy, the stitching together of production processes in multiple nations (the 'global factory'), and the heightened maintenance of transnational ties by migrants and other citizens. A significant proportion of the increase in international trade can be traced to the return of China to the capitalist world economy, and it has become the most important location for offshore manufacturing for export to the developed economies. Both changes are closely related to the influx of foreign investment.

The source of the vast majority of FDI was from ethnic Chinese outside the People's Republic of China (PRC): Hong Kong, Macau, Taiwan, and overseas Chinese in Southeast Asia and elsewhere. Although Hong Kong and Macau have been part of the PRC since 1997 and 1999 respectively, they are still administered as Special Administrative Regions under the 'one country, two systems' formula.

It is particularly remarkable that the second or third (depending on which period is discussed) largest source of FDI, Taiwan, is officially still at war with the People's Republic of China regime. Ronald Keith (2001) has recently analyzed the contribution of the concept of 'strategic ambiguity' in maintaining peace in the East Asian region. While the concept of strategic ambiguity has a specific connotation in the study of American policy, here we examine the strategic and tactical use of policies and representations that can be understood in dual or multiple ways in a broader sense. Such deliberately ambiguous representations of practices and intentions have been of crucial importance for the PRC in issues relating to Taiwan, capitalism, and the nature of the 'socialist market economy' and thus has been critical in facilitating the absorption of foreign capital and promoting economic reforms. Despite its advantages, particularly in terms of domestic politics, leaving certain things unsaid and unclear has both facilitated and hampered foreign investment in reform China. ${ }^{3}$ One result was that until accession to the World Trade Organization, FDI has primarily come from investors with a higher tolerance for the risks posed by uncertain property rights and a level of political risk that was difficult to assess. For various social, economic and political reasons, the risk-tolerant investors tended to be ethnic Chinese, particularly Hong Kong entrepreneurs who also had the advantage of geographic proximity. In addition, the sensitivity of economic dealings with capitalists in the early reform years made it easier to deal with investors who could be referred to as 'patriotic' Chinese rather than capitalist profit-seekers. The result was that various tax and regulatory advantages were given to ethnic Chinese investors, particularly the 'compatriots' (tongbao) of Hong Kong, Macao and Taiwan. 
In this article, we will first examine the impact of FDI on China's post1979 economic transformation. Then we will focus in more detail on how FDI was absorbed into early reform China, examining the ways in which ambiguity was mobilized by both sides to deal with the incompatibilities between the political economic systems. Following that, we will argue that the patterns of transnational connections have been transformed by the maturation of China's economy, and particularly by the recent shift towards a knowledge-intensive, high-technology economy. The forms of transnational economic cooperation that facilitated the boom in labor-intensive manufactured exports have become less appropriate in the current situation. We argue that rather different patterns of cooperation (especially linkages based on education rather than kinship or shared native place) between Taiwan and Silicon Valley are being transferred into China's high-tech sector. These forms of transnational communities may be becoming more important as the earlier versions decline in relevance.

\section{THE ECONOMIC REFORMS AND FOREIGN DIRECT INVESTMENT}

Almost a quarter of a century after Deng Xiaoping's economic reforms, it is easy to forget how (counter)revolutionary it was for China to admit capitalist investment in 1979. At least at first, it was clear that the 'capitalist road' could easily be reversed again, with serious risks for its proponents. Tentative early versions of the Open Policy reflected the trepidation with which China's leaders began to flirt with the enemy. As a result, China's economic reforms followed a path of indirection, ambivalence and gradual acceptance of what previously would have been anathema. ${ }^{4}$ The crisis of Maoism combined with the rise of Asian Newly Industrializing Economies to encourage the post-Mao leadership to permit elements of markets and capitalism while endeavoring to control them and euphemistically label them. ${ }^{5}$ Early efforts were limited by size and place: petty production and commerce and special economic zones.

The locations of the special economic zones were strategically located in areas bordering Hong Kong, Macau and Taiwan and where high levels of emigration had occurred. Émigré Chinese investors could be portrayed as motivated by patriotism, and not just as agents of a capitalist system intent on suborning Chinese communism to its will. For overseas Chinese investors as well, motivations were often a complex blend of wanting to contribute something to one's native place, or one's relatives, and pursuing profit from newly open pastures. ${ }^{6}$ For China, capitalism was the enemy, but one with which it seemed that some degree of accommodation was inevitable, or at least temporarily strategic for the longer term project of building communism. China's goals were both to absorb and to control foreign investment, and particularly to preserve central control over society. ${ }^{7}$ The initial problems posed by apparently contradictory goals were reduced in part by relying on groups of foreign economic actors who might hold feelings of patriotism and obligation to China, and who often have economic cultures more similar to or at least compatible with those found in China. ${ }^{8}$ By relying on shared expectations and 
practices, the need to rapidly transform institutions and rules could be reduced or at least delayed.

Reliance on foreign trade partners who were willing to go along with Chinese ways reflects an important point: that for most of the Open period, regulation has been more important than has liberalization. As David Zweig indicates, China since 1979 has continued a long history of mercantilist efforts to control foreign influences even while benefiting from them. In this vein,

the Chinese state established an array of regulatory constraints whose goal was to help bureaucrats control foreign and domestic forces. Thus China's opening to the outside world was not a free-market one. Administrative units and legal institutions ... constrained the way domestic interests pursued global transactions. ${ }^{9}$

The conflict of economic pragmatism and political symbolism meant that much of what was being done had to be done at first in tacit rather than explicit ways. One result was that the system of regulation did not provide adequate support for the new practices that were emerging. In consequence the new practices could be done very differently from one locality to another, with results ranging from the corrupt and near-disastrous to remarkable 'economic miracles'. The transformation of China's economy involved considerable experimentation at the local level, followed only afterwards by formal changes to legitimate innovations that are judged by the central authorities as worth promoting. A great deal of local diversity of economic regulation has developed as a result. Strategic ambiguity operates at all levels in this system: between Washington, Beijing and Taipei; between foreign investors and government officials; between local governments and the center; between formal rules and informal practices. Ambiguity of the rules meant that bureaucratic behavior was only loosely constrained, and local responses to these opportunities 'facilitated the weakening of China's regulatory regime'. ${ }^{10}$

Regulatory uncertainty and political sensitivity towards following the capitalist road have over time been replaced by a much greater degree of routinization, beginning particularly after 1989 and formalized in the commitments undertaken by Beijing in return for being allowed to join the World Trade Organization (WTO). ${ }^{11}$ These circumstances have also unleashed a much greater flow of FDI from North American and European corporations, and have reduced the advantages previously held by those pioneers who were willing to take the risks of uncertain property and political systems.

Utilized FDI between 1979 and 1999 amounted to a total of \$307.6 billion, of which Hong Kong accounted for $\$ 154.8$ billion, half of the total, and Taiwan for $\$ 23.86$ billion (7.76 percent). In all, Asia accounted for 76.79 percent of the accumulated total, compared to only 7 percent for the combined EU countries and 9 percent for the United States ${ }^{12}$. FDI inflows started soaring after Deng Xiaoping's famous 1992 'southern tour' launched a new set of reforms. The quantities expanded from $\$ 11.01$ billion in 1992 to $\$ 45.46$ billion in 1998 , and reached $\$ 52.7$ billion in $2001 .^{13}$ 
While the inflow of FDI is often seen as an indicator of China's successes, or of the potential of its domestic market, Huang Yasheng has launched a trenchant critique of the emphasis on FDI in China's reforms. He argues that the high levels of FDI recently achieved by China represent weaknesses more than they do strength. ${ }^{14}$ FDI has come to play a very large role in the Chinese economy, ${ }^{15}$ not because all of the foreign firms are:

the world's best-practice firms but because they are uniquely positioned to exploit many of the business opportunities in China created by China's inefficient economic and financial institutions. ${ }^{16}$

With a gross savings rate of 41.76 percent, one of the highest in the world, China is not short of domestic capital, but domestic capital is systematically disadvantaged. Domestic firms often need foreign partners to export, to obtain foreign currency, even to be able to do business in other provinces. Banks are forced to provide capital to cash-strapped state-owned enterprises (SOEs) rather than potentially successful town and village enterprises (TVEs) and funds move from deposit-surplus to deposit-deficit regions. One of the results of this situation is that 'efficient but private firms are denied access to China's vast savings pool and are too liquidity-constrained to finance their business expansions ${ }^{17}$ and are forced to deal, often disadvantageously, with foreign capital. China is selling valuable assets at prices that are much lower than could be attained if domestic firms were free to compete. Furthermore, much of the recent FDI does not create new productive capacity, but instead serves to transfer assets from SOEs to foreign investors. ${ }^{18}$

Given this critique, we must ask whether FDI helps to compensate for some of these economic weaknesses or exacerbates them. At least until 1992, there seems to be evidence that the contributions were on balance positive. This can be seen particularly in the crucial areas of providing information about world market conditions and providing the expertise and contacts that facilitated the rapid expansion of hard-currency exports. ${ }^{19}$ While current account surpluses and substantial hard-currency reserves may have provided buffers that allowed the delay of economically important but politically difficult decisions such as SOE reform, they also generated profits that attracted agents from throughout the system to press for measures that would allow them to internationalize. It also seems politically very unlikely that more radical domestic reforms could have been adopted first. As Naughton points out, 'growing out of the plan' fostered domestic constituencies that could pressure the state for further reform, and as Zweig demonstrates, produced internal competition for the permissions that allow localities to pursue foreign capital. This competitive process frequently undermined various central state controls as localities selectively re-interpreted rules to make themselves more attractive sites for foreign investment. ${ }^{20}$

Huang does recognize that Hong Kong and Taiwanese investors made contributions to China's rapid economic growth. In a backhanded compliment, he argues against positive evaluations of China's gradualist ('crossing the river by feeling for stones') reform strategy by asserting that China's economy 
managed to grow 'despite its massive institutional imperfections due to its developmental stage (underutilized human capital in the agricultural sector) and as a result of luck: the nearby location of Hong Kong and Taiwan'. Without its ties to ethnic Chinese capital, he says 'nonstate firms would have atrophied under the weight of the lending bias'. He also recognizes that the underdevelopment of the rule of law inherent in the gradualist strategy 'would have deterred foreign investment if not for ethnic Chinese firms that possess relationship capital and cultural know-how that help foreign firms navigate China's murky business environment'. ${ }^{21}$ Expatriate capital, then, took on a particularly crucial role in the early reform years, even if its significance is declining in the post-WTO era.

Some studies provide evidence that is less negative about the impact of FDI. For example, between 1995 and 1999 the share of labor-intensive industries in foreign-invested manufacturing dropped from 50.42 percent to 41.44 percent, while that of technology-intensive industries increased from 26.86 percent to 33.21 percent. $^{22}$ Taiwanese investors at first concentrated on labor-intensive production, but have recently been key actors in the rise of high-technology industries in China, as we discuss later.

Another crucial question concerns the extent to which investment attributed to Hong Kong can actually be considered to be Hong Kong capital. In the first 15 years of the Open Policy, a considerable but difficult to estimate proportion of Hong Kong investment represented disguised subcontracting for Western manufacturers who took advantage of the policy advantages and cultural skills of Hong Kong intermediaries. The Hong Kong corporation Li \& Fung has taken this role to remarkable lengths under the more fashionable rubric of 'supply chain management'. At present, there is considerable discussion of the extent to which Hong Kong investment is in fact 'round-tripping': domestic Chinese capital that is relocated to Hong Kong in order to take advantage of various tax and regulatory advantages, as well as involving the laundering of the proceeds of corruption. The World Bank has estimated that as much as 50 percent of recent Hong Kong investment is actually 'recycled' mainland money. While others suggest that it might be as low as 20 percent, the existence of the practice is not contested. However, a parallel process has involved the rise of the Virgin Islands and other tax havens as large sources for FDI inflows to China. The Virgin Islands, for example, increased its share from zero in 1996 to 9 percent in 1998. In 2001, these tax havens were responsible for 14 percent of China's utilized FDI. It is uncertain how much of this capital is of Hong Kong and Taiwanese origin. $^{23}$

While still very important, the role of diaspora Chinese has changed considerably. Hong Kong investment has increasingly turned to large-scale infrastructure and real estate projects, while the coastal provinces have become less interested in low-technology manufacturing and eager to take their place in the high-tech future. Enclave economies focused on export processing are being replaced with industries that focus on the attractions of the Chinese domestic economy as well as the sourcing of goods for global production networks. Hong Kong export-processing investment in particular is coming to be seen as a 
feature of the past: low-tech and unlikely to contribute to China's knowledge economy, exploitative of workers, despoiling of the environment, and frequently based on corrupt practices and cronyism. While perhaps suitable for transfer to the less-developed interior, the coastal provinces are increasingly setting their sights on what they see as the future: the current high-tech boom in China. As we discuss below, the nature of the investment strategies and enabling relationships are becoming quite distinct in this field, even as ethnic Chinese investment maintains its importance, particularly that from Taiwan.

\section{THE CHINESE DIASPORA: OBLIGATIONS, KNOWLEDGE AND STRATEGIES}

The main question that we address in this section is the extent to which overseas Chinese investment had different effects, as well as a distinct character, than did non-Chinese transnational corporation (TNC) investment. It has been argued that there is a distinctive and crucial synergy between overseas Chinese investors and local governments in the People's Republic of China, one not found to the same extent or in the same form with non-Chinese FDI. ${ }^{24}$ Thus, the synergy must go beyond factor complementarities, one of the main reasons why foreign investors find China attractive (another is the potential size of the domestic market) ${ }^{25}$ since these apply to both types of capital. Synergy is seen as residing in the specific skill set of Chinese investors (experience with laborintensive exports to the West and with managing to achieve high quality and productivity from unskilled labor), cultural similarities and propensities (shared culture and language, ability to form trustworthy relationships, values of authority and hard work), knowledge of how to get things done in contexts of policy uncertainty while minimizing transaction costs, and industrial structures that tolerate higher levels of regulatory uncertainty and risk ${ }^{26}$.

One set of evidence for the existence of differences is that Western TNCs tended to invest in the large cities, while Hong Kong and Taiwanese investors were much more likely to do business in the countryside, although generally in rural areas with good transportation linkages. Non-local direct investment (that is, foreign plus Hong Kong sourced investment) in the Pearl River Delta of Guangdong province had the effect of reducing regional inequality through the higher concentration of FDI in poorer counties. ${ }^{27}$ Since poorer regions often had higher rates of emigration, the promotion of investment from ethnic Chinese outside China through social connections generates investment in poorer areas that might not attract much interest were it not for the linkages. At the same time, cultural familiarity and social connections made the establishment and maintenance of operations in rural areas much easier for Hong Kong and Taiwanese investors than it would have been for North American or European managers. These relationships often made it easier to overcome political and economic incompatibilities as inconvenient rules were often ignored or 'adjusted'.

Hong Kong and Taiwanese investments have generally been smaller individually than Western TNC investments, were typically negotiated at lower 
levels of the government hierarchy, more likely to concentrate on exportprocessing than on gaining access to the domestic market, and less likely to adopt a Wholly Foreign-Owned Enterprises model. ${ }^{28}$ They also tended to rely less on carefully negotiated contracts and more on personal ties and constructing trustworthy relationships. In the uncertain regulatory environment of the early years of the Open Policy, such approaches allowed them to set up their enterprises more rapidly and with lower transaction costs. Guha and Ray have argued that most traditional FDI theory suffers from lumping together TNC FDI and those investments that come from expatriates. They attempt to demonstrate that in low-wage countries, particularly those lacking transparent investment environments, expatriate investors have advantages over TNCs in laborintensive manufacturing because of their knowledge of both global markets and technology and local conditions, languages and cultures. By contrast, TNCs have their competitive advantages in brand names and sophisticated technology, and see FDI in emerging markets primarily as a way of breaking into domestic markets that are closed to exports and where licensing arrangements are too risky or costly to enforce ${ }^{29}$.

Critics have pointed out a number of flaws in the synergy model. First, it tends to assume both the continuation of cultural commonalities and the power of shared identity to facilitate trustworthy business networks which can then operate efficiently with lower transaction costs. This culturalist position ignores internal differentiation among Chinese and takes identity as an unproblematic given. ${ }^{30}$ Second, it assumes that even while social connections are used for business purposes, their basis in solidarity and commonality resolves the problems of conflicting economic interests. Thirdly, even if business ties are more easily constructed and maintained among co-ethnic Chinese, and even if they do generate effective and stable cooperation, the approach 'still risks oversocializing economic behavior that is rooted in business and technological considerations' and thus 'assumes that social relationships determine economic transactions and outcomes'. ${ }^{31}$ While economic relationships are clearly socially and culturally embedded, markets and industries have their own dynamics that reward certain types of organization and practices and drive others towards bankruptcy and failure. In the next section, we argue that the shift from laborintensive export processing towards high-technology industries requires different kinds of supportive social relations. In the remainder of this section, we concentrate on the first two problems with the synergy model, examining how the expatriate capitalist/local government interface is often tense and contested, requiring skilled balancing of conflicting demands in an uncertain environment if the potential benefits are to be achieved. Claims to patriotic duty or the need for kin or natives of the same home town to work together may be rejected tacitly, even when acknowledged explicitly. The conflicts and tensions generally go without saying.

Reliance on social relationships to organize economic activity is widely seen as important enough to warrant discussion of a distinctive variety of economic organization found among ethnic Chinese and sometimes known as guanxi capitalism, or more formally as a reliance on network forms of 
governance. Outside the PRC, the utilization of guanxi has been more commonly seen in a context of the desirability of maintaining flexibility and being rapidly able to respond to changes in market demand. However, it is clear that reliance on law or networks is not an either/or kind of situation. Networks can still be important where legal protections are reasonably unambiguous, and legal protections can be pursued when social relationships are the main source of reliable interaction. In certain cases, the availability of reliable rule of law may facilitate the development of guanxi, or at least a tamed version of it, rather than inhibit it.

Douglas Guthrie has argued that rather than increasing with economic reforms since 1978 as Mayfair Yang claimed, the significance of guanxi has actually declined during China's economic transition. ${ }^{32}$ This discourse of the declining significance of guanxi is often linked to a critique of the earlier forms of FDI from Hong Kong. Shanghai sees itself as more organized and efficient than the rather chaotic practices of Southern China. The changes that Guthrie documents as a decline in the significance of guanxi may be better seen as representing more effective controls on blatantly manipulative forms of guanxi practice related to cadre power. ${ }^{33}$ Guthrie's study demonstrates that in the urban industrial economy, guanxi practices that allow actors to go around the law and grossly manipulate institutional procedures are now more likely to result in reprobation and failure, but this does not mean that guanxi is certain to fade away. After all, guanxi is far from insignificant in Hong Kong and Taiwan; it has simply been domesticated in such a way as to be more or less limited by the rule of law and concerns of economic efficiency. Our argument here is that while strategies of reliance on personal relationships may not always succeed, neither are negative outcomes certain.

Economic governance in China has become much more routinized and transparent in the last ten years, particularly in response to the requirements placed on China if it wished to become a member of the WTO. Nicholas Lardy argues that the concessions made by China required substantially more liberalization than exists in many other low-and middle-income WTO members. ${ }^{34}$ These new arrangements have reduced the advantages of those expatriate capitalists who have knowledge of how to get things done in uncertain and politically driven contexts, and increased the advantages of Western TNCs. Western TNCs are also seen as having crucial assets that are in short supply among Hong Kong investors: brand names and cutting-edge technology. Thus, the flexibility, tolerance for uncertainty, social connections, and political knowledge that Hong Kong investors used to be the predominant agents in FDI in China are becoming less important in current conditions. However, the reduced desirability and need for this kind of investment should not blind us to how crucial it was when China was only tentatively opening the door to capitalist investment. Strategic ambiguity may have largely given way to transparent and universal rules, but without the contribution of ethnic Chinese investors that could be portrayed as 'patriotic' rather than 'capitalist', the reform experience would certainly have taken very different paths. ${ }^{35}$ 
OVERSEAS CHINESE TECHNICAL COMMUNITY AND

TECHNOLOGICAL UPGRADING: SILICON VALLEY-TAIWAN CONNECTION

The economy cannot be reduced to interpersonal relationships, as it is composed of multiple production worlds defined by product configuration, market principles and technology and production processes. ${ }^{36}$ In other words, dense social ties cannot normally substitute for the sophisticated managerial and technological learning that is required to compete in a particular sector. Guanxi arguments tend to overlook these complex differences, although in contexts where institutional barriers to business operations are unusually great they may identify sources of competitive advantage. Nevertheless, we will argue that guanxi, rather than simply declining, would work in another way in knowledgeintensive industrial sectors. In fact, guanxi (or ethnic social capital) could lubricate economic transactions, only if both transacting parts possessed complementary assets. ${ }^{37}$ Instead of focusing on the strength of guanxi in the Chinese business connection, it would be better to discover the new lubricating role played by informal institutions in linking entrepreneurship and talents in the knowledge-intensive sectors.

This form of cooperation is particularly critical in the current business environment, characterized by short product cycles, knowledge intensivity and network orientation. ${ }^{38}$ High-technology industries are noted for the continuous refinement of their products, markets and technologies, and product cycles shorter than a few months. Rather than exploiting cheap resources, firms with competent business models are looking for qualified and skilled teamwork enhancing human capital. Moreover, independent enterprises today produce all of the components that were once internalized within a single large corporation - from application software, operating systems and computers to microprocessors and other components. The final systems are in turn marketed and distributed by still other enterprises. Within each of these horizontal segments there is increasing specialization of production and a deepening social division of labor. In the semiconductor industry, for example, independent producers specialize in chip design, fabrication, packaging, or testing, as well as in different segments of the manufacturing materials and equipment sector. A new generation of firms emerged in the late 1990s that specialize in providing intellectual property in the form of design modules rather than the entire chip design. There are, for example, over 200 independent specialist companies in Taiwan's integrated circuit (IC) industry alone. It is the global production networks, rather than the large transnationals themselves, that constitute the pillar of the world economy. ${ }^{39}$ The deepening social division of labor in the industry creates opportunities for innovation in formerly peripheral regions opportunities that did not exist in an era of highly integrated producers.

In the new environment, flexibility becomes the catchword for competitive advantage, and clusters of specialist firms are better positioned to enhance collective responsive capabilities. ${ }^{40}$ The key to success in the rapidly-changing market lies in capabilities to identify the right people (know-who), and 
accordingly fix the right technologies and products (know-how), as more innovations are human-embodied and team-working. ${ }^{41}$ It is the learning capabilities, not existing endowments, that constitute firms' and regional competitive advantage in the new economy. ${ }^{42}$ Moreover, as Lundvall argued, the learning process involves more than purchasing technology, and includes social dimensions such as the absorption of tacit knowledge, which is embodied in technical staff. ${ }^{43}$ No doubt ethnic ties and interpersonal relationships can facilitate collaboration, reduce the uncertainty of economic deals, identify key resources and recombine them in new ventures. Shared language and cultures can help producers, even those located at great distances, gather information about people, capital, and other resources within the community. Therefore, building up capabilities in identifying know-who in the cross-border technology learning will be a primary issue for a late industrializer such as Taiwan to meet the challenge of global competition. To a certain extent, transnational sociotechnical communities provided the networks for Taiwan to tap into the hightechnology hub in Silicon Valley ${ }^{44}$.

Accounting for technical upgrading in late-industrializing regions is a contested issue. While some top-down accounts, such as that of Alice Amsden, ${ }^{45}$ suggest that the developmental state and key big companies (national champion) should be put at center-stage in the process of late-industrialization, other accounts focus on global production networks and argue that late development benefits from its insertion into global value chains. ${ }^{46}$ Both are partially true, but fail to take seriously the embedded institutions in trans-border connections between technologically leading and following regions. In fact, as discovered by Saxenian, Taiwan's links with the Californian technology hub unfold in several ways: Taiwan's companies recruit overseas engineers, they set up listening posts in Silicon Valley to tap into the brain power there, or successful overseas engineers return to Taiwan to start up their own businesses. $^{47}$ All of these possible links are established smoothly not only on an individualistic basis, but largely through the mediation of overseas organizations. The central and largely unrecognized actors in this process are a community of US-educated engineers who have built a social and economic bridge linking the Silicon Valley and Taiwan economies.

The development of a transnational community - a community that spans borders and boasts as its key assets: shared information, trust, and contacts ${ }^{48}$ has been largely overlooked in accounts of Taiwan's accelerated development. The social structure of a technical community appears essential to the organization of production at the global as well as the local level. It is a kind of community of practice, ${ }^{49}$ a group with shared beliefs about technological trends and ways of doing things, and it has expanded unexpectedly across the Pacific.

The experience of Taiwan has demonstrated the possibility of industrial upgrading through inter-regional cooperation and the reversal of 'brain drain' in the developing countries. Rapid growth of the Taiwanese economy in the 1980s, combined with active government recruitment ultimately reversed the 'brain drain'. Lured primarily by the promise of economic opportunities, as well as the 
desire to rejoin their families and contribute to their home country, growing numbers of US-educated engineers returned to Taiwan in the 1990s. The Silicon Valley-Taiwan business connection was institutionalized in 1989 with the formation of the Monte Jade Science and Technology Association. Monte Jade was started in 1989 by a group of senior Taiwanese executives with the intention of promoting business cooperation, investment, and technology transfer between Chinese engineers in the Bay Area and Taiwan. Monte Jade actively promotes entrepreneurship as well: a reflection of the extent to which the Taiwanese immigrants have adopted the Silicon Valley business model. A special committee of the Board of Directors offers assistance to individual members who are considering starting companies regarding corporate formation, growth, and development. It also helps member firms with the flow of investment funds, technology transfer, and mergers and acquisitions.

In spite of ethnic ties that facilitate cross-Pacific technological cooperation, the technical community benefits more from integration with broader business networks. It is clear that the overseas diaspora helped transfer technology and business models back to Taiwan. It is particularly true that while the Taiwanese firms in both regions had to rely on ethnic ties with mainstream businesses during their embryonic stages, guanxi could ease information collection across the Pacific. Trust and reciprocity incubated from primary ethnic bonds and informal personal relationships facilitate cooperation between these regions, and broaden the scope of guanxi building. However, the key to sustainable growth resides in the complementary assets possessed by the transacting partners, Taiwan and Silicon Valley.

It is the transnational technical community that allows distant producers to specialize and collaborate to upgrade their capabilities, particularly when collaboration requires close communication and joint problem-solving. The trust and local knowledge that exist within technical communities, even those that span continents, provide a competitive advantage in an environment where success depends on being very fast to market. However, these highly skilled Taiwanese immigrants are distinguished from the broader Chinese Diaspora (or 'overseas Chinese business networks') by shared professional as well as ethnic identities and by their deep integration into the technical communities of both technology regions.

Trust is the key component created by guanxi to lubricate inter-firm interactions. However, even if guanxi-embedded trust does matter in the transaction process, we still have to distinguish trust incubated by ethnic ties from that bred by learning. In most cases, firms place subcontracting orders to other firms, even with close ethnicity or classmate ties, with a small volume in the beginning, and then put in more orders after reviewing the first ones based on merit. It is the transacting process that thickens the social fabrics, more than vice versa. In principle, guanxi provides the basic ingredients for the two regional ethnic communities to build up trust for business in the beginning. However, trust should be monitored to refine, and thus could develop to allow lasting cooperative behavior. Although these two types of trust cannot be empirically separated, they should be treated as different theoretically. Guanxi-embedded 
trust helps the cross-border firms engaging in initial cooperative business, but monitoring-created trust ensures the deepening of these deals. While we agree that guanxi and cultural affinity could provide the channel for valuable information, we disagree that interpersonal relationship itself would create a faithful collaborative industrial community. In Chen's terminology, in this context effective guanxi plays the role of lubricant which enhances the transaction, not that of glue which fixes the transaction. ${ }^{50}$ We do not argue here that there are inevitable contradictions between social ties and economic rationality, ${ }^{51}$ but that distinguishing between different forms of trust and their embodied functions in business activities is essential for effective analysis. ${ }^{52}$

\section{OVERSEAS CHINESE NETWORKS AND HIGH-TECHNOLOGY DEVELOPMENT IN CHINA}

The connection between Taiwan and Silicon Valley through the mediation of transnational ethnic-technical community is not unique. ${ }^{53}$ As China promotes high-technology sectors, such as computer and semiconductor industries, two sources of overseas linkage will benefit development in the new sectors. One is the extension of Silicon Valley-Taiwan connections to China through attracting Taiwanese high-technology investments. Another one is repeating Taiwan's experience and building up Silicon Valley-China connections by recruiting back talented individuals. These two trends sometimes penetrate each other and constitute a triangle connection.

By the mid-1990s, a decade after Taiwanese SMEs (small and medium enterprises) first went to China, the majority of the cross-strait investments shifted from traditional sectors, such as garments and footwear, to informatics industries, particularly personal computer (PC) components and peripherals. ${ }^{54}$ An acute labor shortage and relatively high cost triggered the emigration of Taiwanese PC industries, starting from the most labor-intensive and pricesensitive keyboards and PC mice to power supply units, and then to motherboards and monitors. ${ }^{55}$ In undertaking cross-strait investments a series of governance and coordination issues was posed for Taiwanese PC firms. The first question was the location of the new plant. Most Taiwanese PC firms chose PRD (Pearl River Delta) and YRD (Yangtze River Delta) as their destination. In fact, the locale of Taiwanese investments, particularly those high-technology investments such as laptop computer and integrated circuit industries, has concentrated in the YRD region, as Figure 1 shows.

As China's entry to WTO became all but certain in the late 1990s, a number of Taiwanese investors started setting up new companies to be responsible for marketing on the mainland, ${ }^{56}$ or at least split up the local marketing division from other departments in the firm's organization. The role of ethnic social ties benefited the collaborative projects between Taiwanese high-technology firms and their Chinese counterparts in developing new products and exploring new markets.

On the one hand, by subcontracting the major electronics groups in China, such as Legend Computer, helps Taiwanese SMEs to penetrate the local 
FIGURE 1

THE GEOGRAPHICAL DISTRIBUTION OF TAIWANESE IC AND NOTEBOOK COMPUTER INVESTMENTS IN MAINLAND CHINA

(a) IC Industry

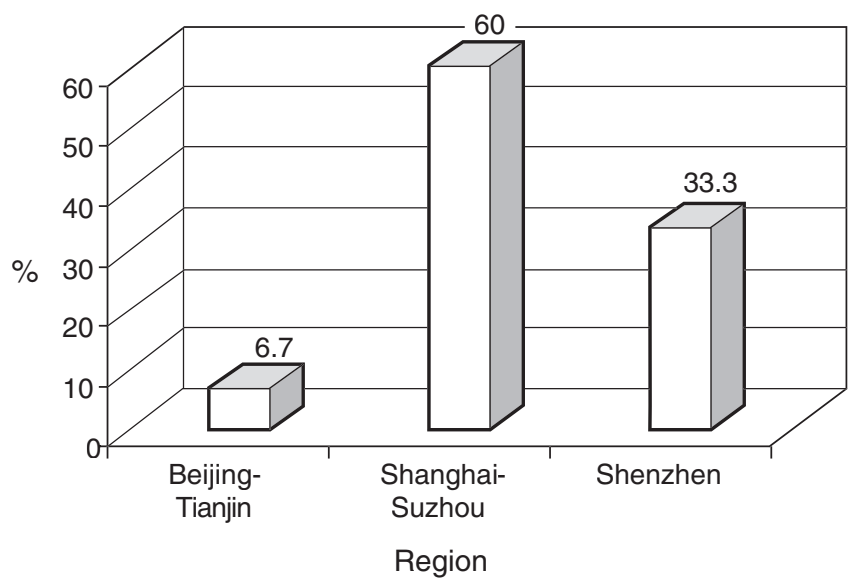

(b) Notebook Computer

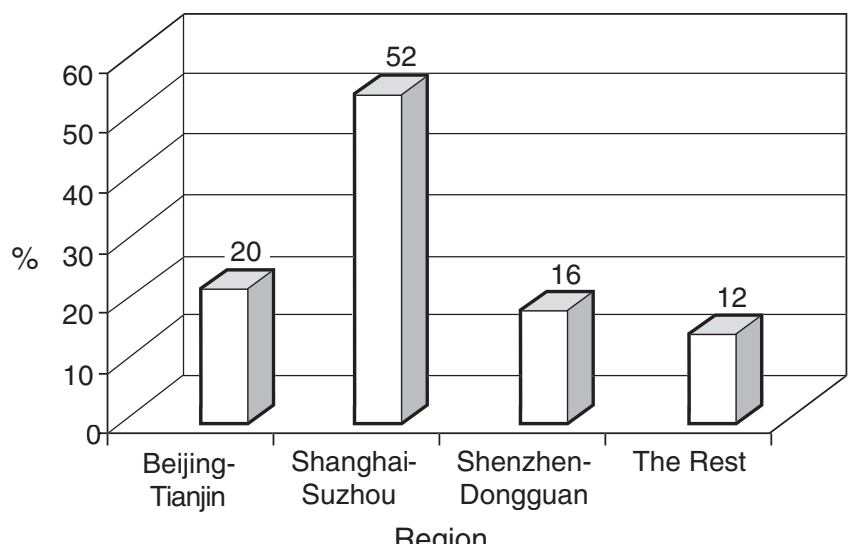

Region

Source: Capital Business Group, The Special Issue on Taiwanese Investment in China (Taipei: Capital Business Group, 2001).

market, which appeared seemingly open but really maintained tremendous barriers. $^{57}$ On the other hand, collaboration could also extend to new differentiated product development, which might match the local demand. Take the collaborative project between Taiwan's First International Computer (FIC) Group and China's Legend Computer Group as an example. To facilitate the collaborative project, FIC sent out a team of several key engineers to Legend's new plant in Shanghai to develop new products such as notebook 
computers. In return, FIC established a stable subcontracting relation with the largest local computer group in China. ${ }^{58}$

Another famous instance was the joint ventures made by Foxconn Group with promising start-ups founded by local engineers to access the emerging product areas for wireless telecommunication, in which China's innovation base was believed to be more competitive than its counterpart in Taiwan. These investments were to target new product development, and to enhance the innovative activities for the Foxconn Group in China. ${ }^{59}$

The local market imperative is not just confined to Taiwanese investors' usual practices of playing subcontracting partners for key PC buyers, but also extended to envision the possibility of metamorphosing as own brand-name (OBN) makers with a high profit margin. Becoming an OBN producer was totally a new and knotty practice for most of the Taiwanese PC investors, who were well known for their hidden Original Equipment Manufacturer (OEM) factories in their global production networks. It required not only the production capabilities, which most Taiwanese PC investors knew quite well, but also the marketing competence, which included tacit knowledge about local tastes, specific standards, and exact regulations, to make a way into the long-protected China market. Besides collaboration with local customers like the FIC-Legend case, a number of Taiwanese investors had to recruit local talents who had better sales experience to run the newly-added marketing division. Acer Peripherals hired a group of local managers, including those who had spent several years in State Owned Enterprises, to strengthen its task force in pursuing the China market, according to Mr. Lee, the chief executive officer (CEO) ${ }^{60}$ Inventec Group was also noted for its early establishment of local innovation teams to develop products (for example, translator appliances) and sell the products locally. As Mr Huang, vice president of Inventec (Shanghai) indicated, 'We had been OEM partners for key international electronics buyers for a long time. We could never dream of creating our own brand products until we arrived at Shanghai. But selling products in China was not a piece of cake, even though we Chinese shared the same culture. But the same culture helps us to identify the right people to take charge of local markets. So, we hired local qualified people with product design capabilities and marketing experiences to lead the division. They usually needed guidance in the beginning, but they could adjust themselves very quickly.' 61 After localization efforts, a number of Taiwanese investors started their own brand of products, such as Acer Peripherals who switched from a member of Acer group to BenQ brand maker; Quanta Computer, the largest notebook maker in the world, sold its products in the name of Getac in China; and Inventec Group promoted its Okwap cellular phones in the domestic market in 2001.

Together with capital flows, movement of engineers has become conspicuous recently. Due to political reasons, the central governments tried to restrict the flow of engineers either from Taiwan to China or vice versa, nevertheless, these restrictions failed in the end. Going to Shanghai has become one of the top options for Taiwanese engineering graduates recently, according to a manpower survey. ${ }^{62}$ It was reported that SMIC (Semiconductor Manufacturing Interna- 
tional Corporation), the largest and most advanced Chinese semiconductor firm, recruited over 300 engineers from the ex-employees of TSMC (Taiwan Semiconductor Manufacturing Corporation), Taiwan's largest IC firm, to Shanghai. It is believed that thousands of Taiwanese engineers and skilled laborers work in China. As China emerges as a source of cheap qualified engineers and an expanding consumer market, more Taiwanese high-technology firms will move parts of their operation inwards to exploit business opportunities. TSMC plans to set up its fabrication house in Shanghai, and will dispatch hundreds of experienced managers and engineers to transfer its operation. It is an open secret that TSMC would be the last of the key hightechnology firms to invest in China, as others have moved in already. The expatriate managers and engineers typically travel back across the straits quarterly, suggesting that these firms continue to rely on their Taiwanese headquarters for strategic decision-making and direction.

While the Taiwan connection has been 'making capitalism' in China since the early 1980s, ${ }^{63}$ a new connection with Silicon Valley has been emerging since the late 1990s. Many Chinese engineering students who studied overseas have graduated and worked for a few years in key industrial bases such as Silicon Valley. It was reported that of the 320,000 Chinese who studied overseas from 1978 to 1999 , only one in three has returned home. ${ }^{64}$

However, as China's government targeted the development of hightechnology industries, they provided many incentives to attract the 'patriotic' overseas Chinese engineers and entrepreneurs back to fill the shortage of experienced talent in the mainland. Under the efforts of central and municipal governments, 53 nationally recognized science or industrial parks were constructed to foster high technology. ${ }^{65}$ These parks provided various packages of tax and land incentives to subsidize foreign investors. Among them, the Zhangjiang High Tech Park in Shanghai's Pudong New Area was paramount. Zhangjiang Park has emerged as a center of wholly foreign owned investment, which reached $\$ 3.4$ billion in 2000, triple the average in previous years. This contrasts with joint ventures, which accounted for $\$ 659,000$, and domestic ventures, which invested only $\$ 451,000$. Zhangjiang hosted SMIC and GSMC (Grace Semiconductor Manufacturing Corporation), the two largest and most advanced semiconductor fabrication plants in China. These high-technology firms offer opportunities for returnees to combine their overseas experiences with local human resources. For example, the key role of technology development chief at SMIC is held by Mr Simon Yang, a Shanghai native who worked at Intel for 14 years. His colleague, Mr Joseph Xie, the senior director of marketing, also possesses similar working experience of seven years at Intel and AMD in Silicon Valley, and Chartered Semiconductor Manufacturing in Singapore.

Besides employment opportunities in large firms, several programs run by different levels of government agencies, such as the Chun-hui Program, grant financial and manpower support to returned entrepreneurs to start ventures in China. A number of Returning Students Venture Parks were established to target returning entrepreneurs. Combined with the perception of greater stability and 
the large local pool of cheap and capable engineers, these incentives attracted overseas Chinese students back. According to one estimate, one quarter of the more than 200,000 students who studied overseas after 1978 had returned by early $2000 .^{66}$ For example, more than 1,000 returning Chinese electrical engineers have settled in the Shanghai area, and they have founded more than 150 companies, mostly small enterprises. ${ }^{67}$

Similarly to the Silicon Valley-Taiwan connection, China's link was built on the individual level first, but soon became institutionalized by establishing a transnational community. A number of associations and groups were organized to enhance technical and social interaction among the members. At first, these organizations were set up in Silicon Valley, and later they were extended back to the mainland as high-technology infrastructures gradually became available, as has been well documented by Saxenian. ${ }^{68}$ One of the key associations, the Hua Yuan Science \& Technology Association, was formed in Silicon Valley in 2000 to: 'promote the technological, professional and scientific development of the Chinese business community'. Hua Yuan and other Chinese professional associations also sponsor regular business tours to China, receive government delegations, and serve as conduits for Chinese firms recruiting in the US. Through the fora provided by these organizations, two-way channels were established for Silicon Valley's high-technology capital and China's emerging market and manpower.

However, as demonstrated by the case of Hua Yuan, the immigrant engineers from mainland China, a fast-growing presence in Silicon Valley in the 1990s, are creating their own social and professional associations rather than joining those established by their Taiwanese predecessors, such as Monte Jade. This divide underscores the dangers of overstating the power of race or nationality in creating cohesive ethnic identities, which is often taken for granted in discussions of the business networks of the Overseas Chinese. Collective identities are constructed over time, often through the kinds of face-to-face social interactions that are facilitated by geographic, occupational, or industrial concentration. Initial social connections often have a basis in shared educational experiences, technical backgrounds, language, culture and history. Once established, these concentrations promote the frequent, intensive interactions that breed a sense of commonality and identification with members of the same group - and at the same time, exclude others, even of similar racial characteristics.

But we should not hastily conclude that Silicon Valley, today's pre-eminent high-technology hub, has distinctly separate connections with China and Taiwan, as they ultimately share similar technical and business interests. The emergence of the China-Silicon Valley connection also facilitates the crosspenetration between these overseas Taiwanese and Chinese associations; some of them were even initiated by the ostensibly opposed governments on either side of the Taiwan Strait. Despite the rejection of Monte Jade's application to set up a branch office in Beijing by China's government, Monte Jade invited one senior mainland Chinese entrepreneur to join its steering committee. In fact, regardless of political differences, overseas Chinese entrepreneurs who 
originated from Taiwan are eager to introduce the Silicon Valley model to mainland China, as they see tremendous business opportunities there. The list of investors is largely the same as that in early Taiwan-Silicon Valley linkages. ${ }^{69}$ In most cases, the cross-Pacific collaboration would involve not only the capital and technology sending and receiving points (Silicon Valley and China respectively), but also an intermediary role played by Taiwan's high-technology investors.

The case of Acorn Campus is particularly illustrative here. The Campus was mainly established by a team of successful Taiwanese venture capitalists and engineers based in Silicon Valley. It plans to introduce the incubator model to Shanghai and focuses on semiconductor design, wireless infrastructure, and system and software development. It aims to exploit the best resources from different locations: research and development ( $R \& D)$, new product development and marketing in the US, high-end logistics, design and manufacturing in Taiwan, and low-cost engineering and manufacturing talent in China. ${ }^{70}$ Another good example is the case of WI Harper, a venture capital company registered in Silicon Valley with major funds sourced from Taiwan. It assembled a new fund of about $\$ 30$ million in 2001, and allocated 20 percent in Taiwan, 30 percent in China and 50 percent in Silicon Valley to develop new products in biotechnology. By doing so, it will be able to mobilize a variety of talents through high-technology business networks.

In other words, a triangle connection between Silicon Valley-Taiwan-China is emerging and creates a pattern of capital and brain circulation in the nodes of transnational business networks. The power of the transnational technical community is evident, and has become a key force in shaping the global production networks. It originated in Silicon Valley and has been transferred by overseas Chinese (emigrated from Taiwan) entrepreneurs first to Taiwan and then from Taiwan as well as directly from Silicon Valley to China. The dense social and professional networks foster multivarious flows of technology, capital, know-how, and information within the triangle, supporting entrepreneurship in the three regions while also providing the foundation for formal interregional business relations such as consortia, joint ventures, and partnerships.

\section{CONCLUDING REMARKS}

We have argued in this paper that the availability of overseas Chinese capital was an important element of China's effective reincorporation into the global economy. The availability of large populations possessing investment capital and expertise in labor-intensive production and export markets who were willing to accept high levels of risk and uncertainty was a key advantage in China's reform strategy. It allowed them to maintain a high level of strategic ambiguity in a period when collaboration with capitalism was a profoundly contested approach while still enabling capitalist production that could be competitive on world markets. This in turn allowed trade surpluses and foreign currency reserves that enabled Beijing to mollify powerful sectors such as the SOEs and the People's Liberation Army through investment in modernization. The 
characteristics of overseas Chinese FDI have been quite different from those of investments by TNCs, and arguably more appropriate for the needs of early reform China.

We have also argued here, however, that the utilities provided by socially connected expatriate investment in the early reform period have become less necessary and even less useful as the reforms have matured and become more systematic, particularly during the transition to WTO membership. China's ambitions in the high-technology sectors in particular have highlighted the need for different patterns of FDI absorption. Our comparison between the Taiwan-Silicon Valley linkages and the triangular transnational technical community, that is starting to emerge through bringing mainland China into the mix, provides new perspectives on the role of guanxi and strategic ambiguity in expatriate-sourced FDI and China's current developmental dynamics.

Firstly, strategic ambiguity was not just exploited by China's government towards Taiwan and capitalism, but was also conversely used by the overseas Chinese technical community, particularly those originating from Taiwan, to take advantage of the asset mobilization in China. The case of the early exclusiveness of Monte Jade demonstrated that kin and native place ties are not always useful as lubricants in business transactions. Their efficacy depends on the broader social contexts and economic opportunities. The final collaboration between the Taiwanese-origin Monte Jade and the mainlander-initiated Hua Yuan illustrates that the emergence of an overseas Chinese technical community could be possible only under the condition of complementary assets among the triangle regions. It is particularly true as China's large potential market will provide local producers with the opportunity to experiment with, and ultimately innovate, in the field of high-technology industries such as wireless communications.

Secondly, the role played by ethnic ties in the high-technology sectors differs from what has been widely described in labor-intensive industries. Rather than arguing that ethnic social capital will not work in the technology-intensive industries, we contend that its role and style is changed. Ethnic social capital was crucial for reducing transaction costs (or indeed even making investment possible at all in certain circumstances) and enhancing mutual trust in the early stages of overseas Chinese investments in mainland China., After the business environment became clearer and technology-intensive investment became more sought-after, ethnic ties became more important as collective assets which assisted in the identification and recruitment of appropriate talents among overseas Chinese in the United States and across the Taiwan Strait. In other word, such ethnic social ties, rather than simply exploiting the opportunities of a context of transitional chaos combined with large factor complementarities, have come to fulfill the need of 'know-who' in the learning economy in which the social dimension is the key and often-ignored issue in the constitution of competitiveness. $^{71}$

Thirdly, the kind of social ties that are of greatest strategic importance in the high-tech sectors are no longer those founded upon kinship and home town ties. 
Close relatives are unlikely to have the specific knowledge and skills that are needed to be at the cutting edge of technological competition. Instead, the right links are more likely to be found through the weak ties among classmates and joint membership in technological associations. While initially not offering the same degree of trust afforded by strong ties, trusted relationships can be built through the processes of cooperating in small ways first and learning who can be trusted and how they can be worked with. Again, it seems to us a remarkable thing that, in the absence of diplomatic ties between Taiwan and mainland China and when non-governmental organizations are still treated with distrust by Beijing, associations that bring together the two sides of the Taiwan Strait and Silicon Valley are managing to foster a fledgling, inclusive, transnational, and technical community. Thus, although strategic ambiguity has been transformed by the routinization of the Chinese business environment, it still serves some critically important roles at present and into the foreseeable future.

\section{NOTES}

1. Quoted in Ronald C. Keith, " "Strategic Ambiguity” and the new Bush Administration's "China Threat", The Review of International Affairs, Vol. 1, No. 2 (Winter 2001), pp. 1-19.

2. See, for example, Sidney Mintz, 'The Localization of Anthropological Practice: From Area Studies to Transnationalism', Critique of Anthropology, Vol. 18 (1998), pp. 117-33; and P. Hirst and G. Thompson, Globalization in Question (Cambridge, MA: Polity Press, 1996).

3. Alan Smart and Josephine Smart, 'Transnational Social Networks and Negotiated Identities in Interactions between Hong Kong and China', in Michael Peter Smith and Luis Eduardo Guarnizo, Transnationalism from Below (New Brunswick, NJ: Transaction Publishers, 1998), pp. 103-29. This usage draws on a long tradition of ethnographic examination of the strategic use of ambiguity in social interaction, see for example, Pierre Bourdieu, Outline of a Theory of Practice (Cambridge: Cambridge University Press, 1977); and F.G. Bailey, The Prevalence of Deceit (Ithaca, NY: Cornell University Press, 1991).

4. Josephine Smart and Alan Smart, 'Personal Relations and Divergent Economies: a Case Study of Hong Kong investment in China', International Journal of Urban and Regional Research, 15 (1991), pp. 216-33. See also Margaret M. Pearson, Joint Ventures in the People's Republic of China (Princeton, NJ: Princeton University Press, 1991); and Dorothy S. Solinger, Chinese Business Under Socialism (Berkeley, CA: University of California Press, 1984).

5. Alan Smart,' Oriental despotism and sugar-coated bullets: Representations of the Market in China', in James Carrier, Meanings of the Market: The Free Market in Western Culture (Oxford: Berg, 1997), pp. 159-94.

6. Laurence J.C. Ma, 'Space, place and transnationalism in the Chinese diaspora', in Laurence J.C. Ma and Carolyn Cartier, The Chinese Diaspora: Space, Place, Mobility, and Identity (Lanham, MD: Rowman \& Littlefield, 2002), p. 28.

7. Pearson, Joint Ventures, p. 4; Pitman B. Potter 'Foreign Investment Law in the People's Republic of China: Dilemmas of State Control', The China Quarterly, Vol. 141 (1995), pp. 15585 .

8. Hsing You-tien, Making Capitalism in China: The Taiwan Connection (New York: Oxford University Press, 1998); Tseng Yen-fen 'From "us" to "them": Diasporic Linkages and Identity Politics', Identities, Vol. 9, No. 3 (July-Sept. 2002), pp. 383-404; Chen Xiangming, 'Both glue and lubricant: Transnational Ethnic Social Capital as a Source of Asia-Pacific Subregionalism’, Policy Sciences, Vol. 33 (2000), pp. 269-87.

9. David Zweig, Internationalizing China: Domestic Interests and Global Linkages (Ithaca, NY: Cornell University Press, 2002), p. 31.

10. Ibid., p. 88 .

11. Nicholas R. Lardy, Integrating China into the Global Economy (Washington DC: Brookings Institution Press, 2002). 
12. Ministry of Foreign Trade and Economic Cooperation (MOFTEC), available at: http:// www.moftec.gov.cn. Below, whenever statistics on FDI are cited without attribution to a different source, they are obtained from MOFTEC.

13. Chen Chunlai, 'Foreign Direct Investment: Prospects and Policies', in China in the World Economy: The Domestic Policy Challenges (Paris: OECD, 2002), p. 324.

14. Huang Yasheng, Selling China: Foreign Direct Investment during the Reform Era (Cambridge: Cambridge University Press, 2003).

15. The ratio of FDI to gross fixed capital between 1992 and 1998 was 13.1 percent for China compared to 6.9 percent for the United States. See Huang, Selling China, p. 13.

16. Huang Yasheng, 'Internal and External Reforms: Experiences and Lessons from China', Cato Journal, Vol. 21, No. 1 (Spring/Summer 2001), p. 54. In a parallel critique, it has been argued that China has been an underachiever in attracting FDI from the main source countries such as the US, instead relying on Hong Kong et al. See Wei Shang-Jin, 'Why does China attract so little foreign direct investment?', in T. Ito and A.O. Krueger, The Role of Foreign Direct Investment in East Asian Economic Development (Chicago, IL: University of Chicago Press, 2000), pp. 230-61.

17. Huang, 'Internal and External Reforms', p. 58.

18. This process can be seen as a variant of asset stripping prevalent in China's privatization, see Ding Xueling, 'Who gets what, how? When Chinese State-Owned Enterprises become Shareholding Companies', Problems of Post-Communism, Vol. 46, No. 3, 1999, pp. 32-41.

19. Huang, Selling China, p. 18.

20. Barry Naughton, Growing Out of the Plan: Chinese Economic Reform, 1978-1993 (New York: Cambridge University Press, 1995); and Zweig, Internationalizing China

21. Huang, 'Internal and External Reforms', p. 62.

22. Chen Chunlai, 'Foreign Direct Investment', p. 329.

23. Dilek Aykut and Dilip Ratha, 'South-south FDI flows in the 1990s', background paper for Global Development Finance, World Bank, April 3, 2002, p. 18; The United States-China Business Council, March 2002, available at: http://www.uschina.org/statistics/03-01.html. For a broader discussion of the accounting issues at stake, see Linda Low, Eric D. Ramstetter and Henry Wai-Chung Yeung, 'Accounting for Outward Direct Investment from Hong Kong and Singapore: Who Controls What?', in Robert E. Baldwin, Robert E. Lipsey and J. David Richardson, Geography and Ownership as Bases for Economic Accounting (Chicago, IL: University of Chicago Press, 1998), pp. 139-71.

24. Constance Lever-Tracy, David Ip and Noel Tracy, The Chinese Diaspora and Mainland China: An Emerging Economic Synergy (Houndmills: Macmillan Press, 1996); Brad Christerson and Constance Lever-Tracy, 'The Third China? Emerging Industrial Districts in Rural China', International Journal of Urban and Regional Research, Vol. 21, No. 4 (1997), pp. 569-88; George C.S. Lin, Red Capitalism in South China: Growth and Development of the Pearl River Delta (Vancouver, BC: University of British Columbia Press, 1997).

25. Huang Yasheng argues that these explanations for FDI based on investor motivations are inadequate since they do not account as to why domestic firms do not compete for the same opportunities. See Huang, Selling China, p. 42.

26. Alan Smart and Josephine Smart, 'Failures and Strategies of Hong Kong Firms in China: An Ethnographic Perspective', in Henry Wai-Chung Yeung and Kris Olds, Globalisation of Chinese Business Firms (London: Macmillan, 2000), pp. 244-71; Henry Wai-Chung Yeung, 'Local Politics and Foreign Ventures in China's Transitional Economy: the Political Economy of Singaporean Investments in China', Political Geography, Vol. 19 (2000), pp. 809-40; and Hsing, Making Capitalism in China.

27. Jianfa Shen, Kwan-yiu Wong and David K.Y. Chu, 'Regional economic growth and factor contributions in the Zhujiang Delta Region of south China', Asian Geographer, Vol. 20 (2001), pp. $125-51$.

28. Smart and Smart, 'Personal Relations'; Zweig Internationalizing China; and Shi Yi-zheng, Ho Po-yuk and Siu Wai-sum, 'Market Entry Mode Selection: The Experience of Small Hong Kong Firms Investing in China', Asia-Pacific Business Review, Vol. 8, No. 1 (Autumn 2001), pp. 1941.

29. Ashok S. Guha and Amit S. Ray, 'Expatriate vs. Multinational Investment: A Comparative Analysis of their Roles in Chinese and Indian Development', paper presented at the 'WTO, China and the Asian Economies' conference, Beijing, Nov. 2002. Their analysis found that expatriate Chinese have been able to have more impact on economic development in China than in India. 
30. Tseng, 'Diasporic Linkages'; Hsing You-tien, 'Ethnic Identity and Business Solidarity: Chinese Capitalism Revisited', in Laurence J.C. Ma and Carolyn Cartier, The Chinese Diaspora: Space, Place, Mobility, and Identity (Lanham, MD: Rowman \& Littlefield, 2002), pp. 221-35; Alan Smart and Josephine Smart, 'Transnational Social Networks and Negotiated Identities in Interactions Between Hong Kong and China', in Michael Peter Smith and Luis E. Guarnizo, Transnationalism From Below (New Brunswick, NJ: Transaction Publishers, 1998), pp. 103-29.

31. Hsu Jinn-yuh and AnnaLee Saxenian, 'The Limits of Guanxi Capitalism: Transnational Collaboration between Taiwan and the USA', Environment and Planning A, Vol. 32 (2000), p. 1994.

32. Douglas Guthrie, 'The Declining Significance of Guanxi in China's Economic Transition', The China Quarterly, Vol. 154 (1998), pp. 254-82; Mayfair Yang, Gifts, Favors and Banquets: The Art of Social Relationships in China (Ithaca, NY: Cornell University Press, 1994); Mayfair Yang 'The Resilience of Guanxi and its New Deployments: A Critique of Some New Guanxi Scholarship', The China Quarterly, Vol. 170 (June 2002), pp. 459-76; and Smart and Smart 'Failures and Strategies'.

33. His research relied on formal questionnaires administered to employees in SOEs and joint ventures, with a resulting normative bias against the acknowledgment of the respondent's reliance on guanxi.

34. Lardy, Integrating China.

35. For a discussion of how China has reinterpreted 'patriotism' to encourage overseas Chinese to contribute to the building of the nation, see Pal Nyiri, 'Expatriating is patriotic? The discourse on 'new migrants' in the People's Republic of China and identity construction among recent migrants from the PRC', Journal of Ethnic and Migration Studies, Vol. 27, No. 4 (Oct. 2001), pp. $635-53$.

36. Michael Storper and Robert Salais, Worlds of Production: The Action Frameworks of the Economy (Cambridge, MA: Harvard University Press, 1997).

37. Chen/Xiangming, 'Both glue and lubricant' (2000).

38. Manuel Castells, The Rise of the Network Society (Oxford: Blackwell, 1996); Michael Best, The New Competitive Advantage: the Renewal of American Industry (Oxford: Oxford University Press, 2001).

39. Jeffery Henderson et al., 'Global Production Networks and the Analysis of Economic Development', Global Production Networks Working Paper 1, 2002 available at http:// www.art.man.ac.uk/Geog/gpn/wp.html.

40. Michael Best, The New Competitive Advantage: The Renewal of American Industry (Oxford: Oxford University Press, 2001)

41. Mario Amendola and Jean-Luc Gaffard, The Innovative Choice (New York: Basil Blackwell, 1988).

42. Best, The New Competitive Advantage.

43. Bengt-Ake Lundvall, 'The Social Dimension of the Learning Economy', Danish Research Unit for Industrial Dynamics (DRUID) Working Paper, 96-1, 1996 available at http://www.druid.dk.

44. AnnaLee Saxenian and Jinn-yuh Hsu, 'The Silicon Valley-Hsinchu Connection: Technical Communities and Industrial Upgrading', Industrial and Corporate Change, Vol. 10, No. 4 (2001), pp. 893-920; Hsu and Saxenian, 'The Limits of Guanxi Capitalism'.

45. Alice Amsden, The Rise of the Rest: Challenges to the West from Late -industrialization Economies (Oxford: Oxford University Press, 2001).

46. For example, see Mike Hobday, 'The Electronics Industries of the Asia-Pacific: Exploiting International Production Networks for Economic Development', Asian-Pacific Economic Literature, Vol. 15 (2001), pp. 13-29.

47. AnnaLee Saxenian, 'Silicon Valley's New Immigrant High-Growth Entrepreneurs', Economic Development Quarterly, Vol. 16, No. 1 (2002), pp. 20-31.

48. Alejandro Portes, 'Global villagers: the rise of transnational communities', The American Prospect, March-April 1996, pp. 74-7.

49. Etienne Wenger, Communities of Practice: Learning, Meaning, and Identity (Cambridge: Cambridge University Press, 1998).

50. Chen Xiangming 'Both Glue and Lubricant: Transnational Ethnic Social Capital as a Source of Asia-Pacific Subregionalism', Policy Sciences, Vol. 33 (2000), pp. 269-87.

51. Cf. Se-Hwa Wu, 'Dynamic production networks in the IC industry', in Ly-Yun Chang, Corporate Networks in Taiwan (Taipei: Yuan Liou Press, 1999) (in Chinese).

52. Walter Powell 'Trust-based forms of governance', in R. Kramer and T. Tyler, Trust in Organizations (Thousand Oaks, CA: Sage Publications, 1996). 
53. As well noted by Saxenian in 'Silicon Valley's New Immigrant High-Growth Entrepreneurs', the overseas Indians have a software business connection with their motherland, despite being less entrepreneurial than their Taiwanese counterparts.

54. The production value of Taiwan's PC sector reached 3,380 billion US dollars in 1998, and over 29 percent of the value was created by Taiwanese investors in China (see, Wall Street Journal, Oct. 21, 1998). In addition, the ratio of made-in-Taiwan PC products declined from 72 percent in 1995 to 52.7 percent in 1999, and the proportion of made-in-China PC products rose from 14 percent to 33.2 percent at the same period (see Market Intelligence Center of the Institute of Information Industry. The Year Book of Computer Industry, (Taipei: MIC, 2001)).

55. The estimated cost savings (including material cost, direct labor and indirect labor) to Taiwanese PC companies ranged from 22 percent in mice production, to 8 percent in monitor making, in comparison with offshore manufacturing in China in 1993. The range was between 16 percent and 4 percent, in comparison with Malaysia. See Chung Ching, 'Division of labor across the Taiwan Strait: Macro overview and analysis of the electronics industry', in B. Naughton, The China Circle (Washington DC: Brookings Institution Press, 1997), pp. 164-209.

56. For example, the Sky Hawk Computer Group established a new company to take charge of its business with the local key customers, such as the Legend Computer and Haier Group.

57. Even though China promised to open its market to foreign companies as part of the conditions for WTO membership, there still existed many barriers, including preferential procurement policies for local companies by the governments, the existence of so-called 'dukedom' economies providing local protectionism in each province and county, and unreasonably high transportation costs and fees for non-local companies (see Common Wealth, Oct. 2001).

58. China Times, Jan. 9, 2002.

59. China Times, Jan. 29, 2002.

60. Su-Yu Zhuang, Taiwanese High Technology Firms Cluster in YRD (Taipei: Global View Publisher, 2001) (in Chinese).

61. Interview with Mr Huang P., Vice President, Inventec Group (Shanghai), Aug. 16, 2001.

62. Tse-kang Leng, 'Economic Globalization and IT Talent Flows Across the Taiwan Strait: The Taipei/Shanghai/Silicon Valley Triangle', Asian Survey, Vol. 42, No. 2. (2002), pp. 230-50.

63. Hsing, Making Capitalism in China.

64. Electronic Engineering Times, Jan. 14, 2002.

65. Susan Walcott, 'Chinese Industrial and Science Parks: Bridging the Gap', The Professional Geographers, Vol. 54, No. 3 (2002), pp. 349-64.

66. Far East Economic Review, June 15, 2000.

67. Electronic Engineering Times, Jan. 14, 2002.

68. AnnaLee Saxenian, 'Brain Circulation and Chinese Chipmakers: The Silicon Valley-HsinchuShanghai Triangle', unfinished manuscript, available from the author, (2003).

69. A number of famous examples include Ta-lin Hsu of HQ, Lin of Trident Semiconductor, Lip-Bu Tan of The Walden International Investment Group, and Ken Tai of InveStar. See Saxenian and Hsu, 'The Silicon Valley-Hsinchu Connection', for the details of their contribution to the Silicon Valley-Taiwan connection.

70. Saxenian, 'Brain circulation and Chinese chipmakers'; Tse-kang Leng, 'Economic Globalization and IT Talent Flows Across the Taiwan Strait'.

71. Lundvall 'The Social Dimension of the Learning Economy'. 